\title{
The Effects of Work-Family Enrichment on Job and Life Satisfaction of Korean Employees
}

\author{
Tae Sik Rhee ${ }^{1} \&$ Fusheng Zheng ${ }^{1}$ \\ ${ }^{1}$ School of Business Administration, Soongsil University, Seoul, South Korea \\ Correspondence: Fusheng Zheng, School of Business Administration, Soongsil University, Seoul, South Korea.
}

Received: April 30, 2019

Accepted: May 30, 2019

Online Published: June 10, 2019

doi:10.5430/ijfr.v10n5p138

URL: https://doi.org/10.5430/ijfr.v10n5p138

\begin{abstract}
This study emphasizes the importance of work-family enrichment and focuses on job satisfaction and life satisfaction to explain the effects of work-family enrichment. A questionnaire survey was conducted on employees of domestic companies and 280 responses were used for analysis. The analysis showed that work-to-family enrichment had positive effects on both job satisfaction and life satisfaction. And at the same time, family-to-work enrichment also showed positive effects on both job satisfaction and life satisfaction. Further, the results show that work-to-family enrichment had a greater effect on job satisfaction, and family-to-work enrichment had a greater effect on life satisfaction. Finally, the results also showed that the interaction between work-to-family enrichment and family-to-work enrichment did not have a significant effect on job satisfaction or life satisfaction.
\end{abstract}

Keywords: work-to-family enrichment, family-to-work enrichment, job satisfaction, life satisfaction

\section{Introduction}

oday, due to an increase in the number of dual-income couples, greater participation of women in the labor force, and changes in the traditional perception of gender roles, employees are faced with more difficulties in managing work and family responsibilities than ever before (Shein \& Chen, 2011; Major \& Germano, 2006; McNall et al., 2011; Tolulope 2017). Many workers have realized that it is difficult to smoothly carry out the different roles required at home and at work, and to maintain the right balance between work and family (Greenhaus \& Beutell, 1985; Ernst Kossek \& Ozeki, 1998). The work-family conflict caused by this situation is an important cause of deterioration in employees' work and life satisfaction (Ernst Kossek \& Ozeki, 1998; Hahm \& Zheng, 2017; Shi \& Qu 2018), and leads to such outcomes as absenteeism, stress, and turnover intentions (Anderson, Coffey \& Byerly, 2002; Feleke 2018). However, with the development of positive psychology, organizational behavior, and more research on families, many studies focusing on the positive relationship between work and family have emerged (Grzywacz \& Marks, 2000; Wayne, Musisca \& Fleeson, 2004; Wadsworth \& Owens, 2007; Greenhaus \& Powell, 2006; Carlson et al., 2006). Work-family enrichment can be defined as a positive interaction between work and family, and refers to the degree to which experience in one role improves the quality of life in another role (Greenhaus \& Powell, 2006). This is not only an important variable for improving both job and life satisfaction (Carlson et al., 2006; Hill, 2005), but it also has a positive relationship with personal health (Williams et al., 2006; Alsharif \& Shukri 2018). Work-family enrichment can be divided into work-to-family enrichment (WFE) which enhances the quality of family life through work-based experience, and family-to-work enrichment (FWE) which improves the quality of work life through family-based experience (Greenhaus \& Powell, 2006). According to existing studies on work-family interface (Frone, Russell \& Cooper, 1992; Ford, Heinen \& Langkamer, 2007), this bidirectional structure is considered to have different patterns of domain specificity in relation to antecedent and consequence related factors. Specifically, the antecedents of WFE occur in the work domain and the antecedents of the FWE occurs in the family domain. However, and on the contrary, in the outcome factors, WFE occurs in the family domain and FWE occurs in the work domain. However, there are also prior studies on affective outcomes, especially satisfaction, that show different results to this perspective (McNall, Nicklin \& Masuda, 2010; Shockley \& Singla, 2011). Although both WFE and FWE showed a positive correlation with job satisfaction and family satisfaction, WFE showed a greater relationship with job satisfaction and FWE showed a greater relationship with family satisfaction. To better understand the role and effectiveness of work-family enrichment, this study examines how WFE and FWE impact on job satisfaction and life satisfaction. In addition, this study also examined how the 
interaction between WFE and FEW effects on job satisfaction and life satisfaction. By clarifying the relationship between work-family enrichment and job satisfaction and life satisfaction, this study aims to emphasize the effectiveness and importance of enhancement.

\section{Literature Review}

\subsection{Work-Family Enrichment}

Work-family enrichment is a positive concept that occurs at the work-family interface that have some similar concepts (Greenhaus \& Powell, 2006), such as positive spillover (Grzywacz \& Marks, 2000), work-family facilitation (Wayne, Musisca \& Fleeson, 2004; Abosedra \& Sita 2018), work-family enhancement (Wadsworth \& Owens, 2007). WFE occurs when work-based experience improves the quality of life at family and FWE occurs when the family-based experience improves the quality of life at work. The process of enrichment may occur through one of two paths: the instrumental and the affective (Greenhaus \& Powell, 2006). The instrumental path refers to resources obtained from one role directly improving the performance of another role. The affective path refers to resources in one role leading to positive affects within a domain and improving individual functioning in other domains. Positive affects represent valued feelings that reflect positive mood, emotion, or attitudes (Greenhaus \& Powell, 2006: Wayne, Randel \& Stevens, 2006). Individuals with a high level of positive affects tend to be more enthusiastic, alert, energetic, and enjoy what they are doing (Wayne, Randel \& Stevens, 2006; Verma, Stoffova \& Zoltan 2018). For example, a high degree of flexibility at work helps members directly improve their parenting role, or positive flexibility in work indirectly helps with family interactions (Sangakala, Ahmed \& Pahi, 2016; McNall, Masuda \& Nicklin, 2009). The resources that are involved and developed in the process of enrichment include skills and perspectives (e.g. interpersonal skills, respect for individual differences, etc.), psychological/physical resources (e.g. self-esteem, self-efficacy, health, etc.), social capital resources (e.g. information, interpersonal influence), flexibility (e.g. discretion), and material resources (e.g. money).

\subsection{Work-Family Enrichment and Job Satisfaction}

Job satisfaction is a positive condition that a member has about his/her job (Locke, 1976). The general attitude of an individual towards their job is recognized as one of the most important factors in organizational research (Robbins, 2003; Oshagbemi, 2000; Rainey, 2009). Job satisfaction generally depends on the characteristic of the job itself, but may also be influenced by differences in situational factors of the job environment (Herzberg, Mausner \& Snyderman, 1959; Hackman \& Oldham, 1975). The reason that work-family enrichment improves job satisfaction can be found in the affective path of enhancement (Greenhaus \& Powell, 2006; Esiagu, Okoroji \& Anyanwu 2016). Recognizing the variety of resources available to assist them at work will likely lead to higher performance in the workplace, which in turn encourages positive moods and emotions in the workplace. These positive moods and emotions can then be transferred to the family domain. At the same time, when employees recognize that family based resources can help them to better perform their family roles, they will have a more positive moods and more positive emotions about their family, which can also be transferred to the workplace. Further, positive emotion is a leading predictor of job satisfaction (Ali \& Haseeb, 2019; Carlson et al., 2011; Cropanzano, James \& Konovsky, 1993), and employees with high work-family enrichment are more likely to have positive moods and emotions, which will lead to higher levels of job satisfaction. Additionally, according to social exchange theory, when an individual is perceived as friendly and positive, he/she will be obliged to act this way, and will be more likely to give a corresponding reward to the other person based on the principle of reciprocity (Blau, 1964; Onuoha,Umoh \& Ufomba 2017). This can be applied to the work and family interface. When employees feel that supervisor or organization is helping them to manage work and family roles, employees will recognize that they are cared and supported by their supervisor or organization (Jermsittiparsert, 2016; McNall, Nicklin \& Masuda, 2010). Therefore, employees will have more favorable attitude to reciprocate their supervisor or organization on a reciprocal basis. Likely, employees will have more positive attitude and committed in family when they feel supported from the family and finally will be transferred to the work domain.

Hypothesis 1: WFE will have a positive effect on job satisfaction.

\section{Hypothesis 2: FWE will have a positive effect on job satisfaction}

\subsection{Work-Family Enrichment and Life Satisfaction}

Life satisfaction is an evaluation of the quality of life according to one's own standards (Shin \& Johnson, 1978; EmenikeKalu \& Obasi 2016). It involves an individual's cognitive and judgmental processes, and is a characteristic of subjective well-being (Diener et al., 1985). Judgments of life satisfaction depend on comparisons between perceived current standards and perceived appropriate standards, and is not externally imposed. Also, since the 
judgment of life satisfaction differs from person to person, it is necessarily evaluated as an overall judgment of life rather than simple satisfaction with a specific area (Diener et al., 1985; Eleje \& Esomonu 2018). In the work-family interface, job satisfaction has a positive relationship with life satisfaction (Tait, Padgett \& Baldwin, 1989), but more active involvement in the family domain leads to higher life satisfaction (McNall, Nicklin \& Masuda, 2010; Judge, Boudreau \& Bretz, 1994). As described above, individuals gain a variety of resources in the process of performing their work and family roles. These resources can improve performance and have a positive affective in each respective domain, and ultimately improve affects in the other domain, so as to have a positive effect on both work and family areas. Therefore, as individuals increase their work-family enrichment, they will be more satisfied with their work and family, and ultimately will be more satisfied with their overall lives. According to the conservation of resources theory and the Role accumulation theory (Hobfoll, 1989; Sieber, 1974), people are trying to preserve, protect, and expand their resources, and when they engage in multiple roles, they can get more satisfaction than stress and conflict. Therefore, when WFE increases, as FWE increases, individual job satisfaction and life satisfaction will be improved.

Hypothesis 3: WFE will have a positive effect on life satisfaction.

Hypothesis 4: FWE will have a positive effect on life satisfaction.

Hypothesis 5: WFE and FWE will have interactive effect on job satisfaction.

Hypothesis 6: WFE and FWE will have interactive effect on life satisfaction.

\section{Methods}

\subsection{Participants}

The data for this research was collected from a set of questionnaires sent to employees of Korean domestic companies between October 15, 2018 and October 25, 2018. A total of 292 questionnaires were collected. 12 questionnaires were not completely properly or appropriately and were discarded, leaving us with data from 280 questionnaires for analysis. The demographic characteristics of the participants were as follows. Of the total participants $153(54.6 \%)$ were male and $127(45.4 \%)$ were female. $63(22.5 \%)$ of the participants were aged in their $20 \mathrm{~s}, 70(25 \%)$ of the participants were aged in their $30 \mathrm{~s}, 86(30.7 \%)$ of the participants were aged in their 40s, and 61 $(21.8 \%)$ of the participants were at least 50 years of age. $177(63.2 \%)$ were legally married, $95(33.9 \%)$ were unmarried, and $8(2.9 \%)$ were living together. $19(6.8 \%)$ participants had worked for less than 1 year at their current workplace, $80(28.6 \%)$ participants had worked for between 1-5 year at their current workplace, 54 (19.3\%) participants had worked for between 6-10 years at their current workplace, 31 (11.1\%) had worked between 11-15 years at their current workplace, $46(16.4 \%)$ had worked between 16-20 years at their current workplace, and 50 $(17.8 \%)$ had worked for over 20 years at their current workplace. In terms of occupations, 137 (48.9\%) were engaged in management, $71(25.4 \%)$ were engaged in research, 18 (6.4\%) were engaged in manufacturing and production, 16 $(5.7 \%)$ were engaged in service, $12(4.3 \%)$ were engaged in IT/computing, $8(2.9 \%)$ were engaged in business/sales, and $18(6.4 \%)$ were engaged in other occupations. In regards to the type of company the participants were working at, $89(31.8 \%)$ were working in service industries, 63 (22.5\%) were working in manufacturing industries, 21 (7.5\%) were working in distribution and trading industries, $13(4.6 \%)$ were working in IT/Information based industries, and $94(33.6 \%)$ were working in other types of industries. Lastly, in terms of number of children, 124 (44.3\%) had no children, $63(22.5 \%)$ had one child, 80 (28.6\%) had two children, and $13(4.6 \%)$ had three or more children.

\subsection{Measurement}

In this study, WFE is defined as the degree of work-based experience improving the quality of family life and FWE is defined as the degree of family-based experience improving the quality of work life. WFE and FEW was assessed using the 18 items (WFE 9 items; FWE 9 items) developed by Carlson et al. (2006). A sample item was, "My involvement in my work helps me to understand different viewpoints and this helps me be a better family member; my involvement in my family helps me to understand different viewpoints and this helps me be a better worker." Job satisfaction is defined as the positive state that an individual has for his or her job. Job satisfaction was assessed using the 4 items developed by Mossholder, Settoon \& Henagan (2005). A sample item was: "Generally, I am satisfied with my job." Life satisfaction is defined as the cognitive and judgmental process of an individual's life quality. Life satisfaction was assessed using the 5 items developed by Diener et al. (1985). A sample item was, "In most ways my life is close to my ideal." All items are measured by a 7-point Likert-type scale.

\section{Analysis}

In order to verify the validity of the measurement variables, confirmatory factor analysis was conducted first in this study. The results showed as follows. In the absolute fit indexes, $X^{2}(p)=516.230, X^{2} / d f=1.792$, RMSEA $=.053$; in 
the incremental fit indexes, AGFI $=.846, \mathrm{TLI}=.971, \mathrm{CFI}=.977, \mathrm{IFI}=.977$; in the parsimony adjusted indexes, $\mathrm{PNFI}=.778, \mathrm{PGFI}=.672 . \mathrm{In}$ addition, the results of construct reliability (C.R), WFE $=.937, \mathrm{FWE}=.893$, job satisfaction $=.902$, life satisfaction $=.841$ and for average variance extracted (AVE) of each variable, WFE $=.727$, $\mathrm{FWE}=.615$, job satisfaction $=.783$, life satisfaction $=.637$. Therefore, the validity of the measurement instrument was verified.

As a result of the reliability analysis, Cronbach's $a$ value of all variables $(\mathrm{WFE}=.974, \mathrm{FWE}=.934$, job satisfaction $=.949$, life satisfaction $=.902$ ) showed high reliability (that is over .9).

The descriptive statistics of the measured variables and the correlation analysis results are shown in Table 1 . The results showed that WFE had a significant positive correlation with job satisfaction $(r=.677, p<.001)$ and life satisfaction $(\mathrm{r}=.689, \mathrm{p}<.001)$. FWE also showed a significant positive correlation with job satisfaction $(\mathrm{r}=.475$, $\mathrm{p}<.001)$ and life satisfaction $(\mathrm{r}=.506, \mathrm{p}<.001)$.

Table 1. Descriptive statistics and correlation analysis

\begin{tabular}{|c|c|c|c|c|c|c|}
\hline & Mean & $S D$ & WFE & FWE & JS & $\overline{\mathrm{LS}}$ \\
\hline WFE & 4.397 & 1.306 & - & & & \\
\hline FWE & 4.833 & 0.985 & $.590^{* * * *}$ & - & & \\
\hline JS & 4.792 & 1.286 & $.677^{* * * *}$ & $.475^{* * *}$ & - & \\
\hline LS & 4.266 & 1.114 & $.689^{* * * *}$ & $.506^{* * *}$ & $.521^{* * * *}$ & - \\
\hline
\end{tabular}

(WFE=work-to-family enrichment, FWE=family-to-work enrichment, JS=job satisfaction, LS=life satisfaction)

In order to verify the hypothesis, a path analysis was conducted using a structural equation. As a result of the analysis, the fitness indices of the models were $X^{2} / d f=2.161, \mathrm{RMSEA}=.065, \mathrm{AGFI}=.823$, TLI $=.958, \mathrm{CFI}=.963$, $\mathrm{IFI}=.964, \mathrm{PGFI}=.693, \mathrm{PNFI}=.815$. Therefore, the research model was considered appropriate.

The results of the analysis on the path analysis are shown in Table 2. WFE has a positive effect on job satisfaction (Estimate $=.653, p<.001)$ and life satisfaction (Estimate $=.549, p<.001)$. FWE also showed significant positive effects on job satisfaction (Estimate $=.137, p<.05$ ) and life satisfaction (Estimate $=.149, p<.01$ ). Therefore, Hypothesis 1, Hypothesis 2, Hypothesis 3, and Hypothesis 4 were all supported.

Table 2. Path analysis

\begin{tabular}{lllll}
\hline Path analysis & Estimate & S.E & C.R & $p$ \\
\hline WFE -> JS & 0.653 & 0.061 & 10.696 & $p<.001$ \\
\hline WFE -> LS & 0.549 & 0.059 & 9.311 & $p<.001$ \\
\hline FWE -> JS & 0.137 & 0.055 & 2.512 & $p<.05$ \\
\hline FWE -> LS & 0.149 & 0.048 & 3.133 & $p<.01$ \\
\hline
\end{tabular}

Finally, in order to verify the effectiveness of the interaction between WFE and FWE, regression analysis was conducted in this study. However, the interaction between WFE and FWE showed no significant effect on job satisfaction $(\beta=-.250, p>.05)$ and life satisfaction $(\beta=.224, p>.05)$. Therefore, Hypothesis 5 and Hypothesis 6 were rejected.

\section{Conclusion}

\subsection{Conclusion and Implications}

This study emphasized the importance of work - family enrichment, which shows a positive relationship between work and family, and examined its effects on job satisfaction and life satisfaction by classifying the effectiveness of WFE and FWE. In addition, this study also verified that the interactive effects of WFE and FWE on job satisfaction and life satisfaction to improve the effectiveness of enhancement. Research results were as follows: first WFE and FWE showed positive influence on job satisfaction and life satisfaction. This implies that members who experience 
work-family enrichment not only have higher levels of satisfaction with their jobs but also have a higher level of satisfaction with their overall lives; Second, WFE had more influence on job satisfaction and life satisfaction than FWE. This implies that WFE explains a greater role in improving job satisfaction and life satisfaction than FWE. Because members acquire a variety of resources in the process of performing their work and ultimately improve the quality of family life, organizations should provide an adequate level of support for managing the roles of work and family in order to improve the attitude and performance of members; Third, WFE had more influence on job satisfaction than life satisfaction, and FWE had more influence on life satisfaction than job satisfaction. These results are consistent with some previous studies (McNall, Nicklin \& Masuda, 2010; Shockley \& Singla, 2011), indicating that the effectiveness of work-family enrichment has a greater impact on the originating role domain than on the receiving role domain. In other words, WFE has more relevance to work related outcomes, and FWE has a greater relevance to non-work related outcomes (McNall, Nicklin \& Masuda, 2010). Fourth WFE and FWE did not mutually increase job satisfaction and life satisfaction. This result may be seen from the perspective of work and family related identity (Wayne, Randel \& Stevens, 2006). In the work-home interface, individuals are more likely to be involved in a domain if they perceive that the role of one domain is important to the self-concept, so that more emotional benefits will arise in another domain. In addition, a strong identity with either work or family can lead to work-family conflict when someone tries to pursue different values at the same time (Stoner, Hartman \& Arora, 1990; Carlson \& Kacmar, 2000). Therefore, if employees try to strengthen the identity of work and family in order to raise the level of enrichment, there will also be a possibility of work - family conflict.

\subsection{Limitations and Future Study}

This study has the following limitations. In order to emphasize the importance of work-family enrichment, this study focuses only on effectiveness. Future research will need to also focus on those factors that can increase work-family enrichment in order to broaden the research on positive interaction between work and family. In addition, since all variables are measured in the form of a self-reported questionnaire, common method bias may have influenced some of the results. Therefore, it is necessary that future research uses various measurement methods to improve the validity of the results. Moreover, in future research, it will also be necessary to conduct a longitudinal study because the hypothesis is verified through the cross sectional study design. Finally, generalizing from the results of this study is limited because it surveyed only employees in Korean enterprises. Therefore, it is recommended that future studies should be continued with a broader range of samples.

\section{References}

Abosedra, S., \& Sita, B. (2018). Finance-Growth Volatility Nexus: Evidence from Lebanon. Asian Economic and Financial Review, 8(4), 466-477. https://doi.org/10.18488/journal.aefr.2018.84.466.477

Ali, A., \& Haseeb, M. (2019). Radio frequency identification (RFID) technology as a strategic tool towards higher performance of supply chain operations in textile and apparel industry of Malaysia. Uncertain Supply Chain Management, 7(2), 215-226. https://doi.org/10.5267/j.uscm.2018.10.004

Alsharif, D., \& Shukri, N. (2018). Exploring Pedagogical Challenges of ESP Teachers at a Saudi Arabian University. International Journal of Asian Social $\quad$ Science, $8(10), \quad 841-855$. https://doi.org/10.18488/journal.1.2018.810.841.855

Anderson, S. E., Coffey, B. S., \& Byerly, R. T. (2002). Formal organizational initiatives and informal workplace practices: Links to work-family conflict and job-related outcomes. Journal of Management, 28(6), 787-810.

Blau, P. (1964). Exchange and power in social life. New York: Wiley.

Carlson, D. S., \& Kacmar, K. M. (2000). Work-family conflict in the organization: Do life role values make a difference?. Journal of Management, 26(5), 1031-1054. https://doi.org/10.1177/014920630002600502

Carlson, D. S., Kacmar, K. M., Wayne, J. H., \& Grzywacz, J. G. (2006). Measuring the positive side of the workfamily interface: Development and validation of a work-family enrichment scale. Journal of Vocational Behavior, 68(1), 131-164. https://doi.org/10.1016/j.jvb.2005.02.002

Carlson, D., Kacmar, K. M., Zivnuska, S., Ferguson, M., \& Whitten, D. (2011). Work-family enrichment and job performance: A constructive replication of affective events theory. Journal of Occupational Health Psychology, 16(3), 297-312. https://doi.org/10.1037/a0022880

Cropanzano, R., James, K., \& Konovsky, M. A. (1993). Dispositional affectivity as a predictor of work attitudes and job performance. Journal of Organizational Behavior, 14(6), 595-606. https://doi.org/10.1002/job.4030140609 
Diener, E. D., Emmons, R. A., Larsen, R. J., \& Griffin, S. (1985). The satisfaction with life scale. Journal of Personality Assessment, 49(1), 71-75. https://doi.org/10.1207/s15327752jpa4901_13

Eleje, L. I., \& Esomonu, N. P. (2018). Test of Achievement in Quantitative Economics for Secondary Schools: Construction and Validation Using Item Response Theory. Asian Journal of Education and Training, 4(1), 18-28. https://doi.org/10.20448/journal.522.2018.41.18.28

EmenikeKalu, O., \& Obasi, R. (2016). Long-run relationship between marketing of bank services \& the performance of deposit money banks in Nigeria. International Journal of Economics, Business \& Management Studies, 3(1), $12-20$.

Ernst Kossek, E., \& Ozeki, C. (1998). Work-family conflict, policies, and the job-life satisfaction relationship: A review and directions for organizational behavior-human resources research. Journal of Applied Psychology, 83(2), 139-149. https://doi.org/10.1037/0021-9010.83.2.139

Esiagu, L. N., Okoroji, L. I., \& Anyanwu, J. O. (2016). Assessment of the Role of Private Enterprises/Small Businesses on Economic Growth (A Study of Some Selected SME'S in Imo State, Nigeria). International Journal of Economics, Business and Management Studies, 3(3), 127-135

Feleke, A. T. (2018). The Dilemma of Determining Urban Administrative Boundary for Land Administration: The Case of Shire Inda Silase. International Journal of Social Sciences Perspectives, 2(2), 126-160.

Ford, M. T., Heinen, B. A., \& Langkamer, K. L. (2007). Work and family satisfaction and conflict: a meta-analysis of cross-domain relations. Journal of Applied Psychology, 92(1), 57-80.

Frone, M. R., Russell, M., \& Cooper, M. L. (1992). Antecedents and outcomes of work-family conflict: testing a model of the work-family interface. Journal of Applied Psychology, 77(1), 65-78.

Greenhaus, J. H., \& Beutell, N. J. (1985). Sources of conflict between work and family roles. Academy of Management Review, 10(1), 76-88. https://doi.org/10.5465/amr.1985.4277352

Greenhaus, J. H., \& Powell, G. N. (2006). When work and family are allies: A theory of work-family enrichment. Academy of Management Review, 31(1), 72-92. https://doi.org/10.5465/amr.2006.19379625

Grzywacz, J. G., \& Marks, N. F. (2000). Reconceptualizing the work-family interface: An ecological perspective on the correlates of positive and negative spillover between work and family. Journal of Occupational Health Psychology, 5(1), 111-126. https://doi.org/10.1037/1076-8998.5.1.111

Hackman, J. R., \& Oldham, G. R. (1975). Development of the job diagnostic survey. Journal of Applied Psychology, 60(2), 159-170. https://doi.org/10.1037/h0076546

Hahm, S. W., \& Zheng F. S. (2017). Communication by IT decreases the negative effects of work-family conflict on life satisfaction and job satisfaction. International Journal of Applied Engineering Research, 12(20), 9746-9751.

Herzberg, F., Mausner, B., \& Snyderman, B. B. (1959). The motivation to work. New York, NY: John Wiley \& Sons. Inc.

Hill, E. J. (2005). Work-family facilitation and conflict, working fathers and mothers, work-family stressors and support. Journal of Family Issues, 26(6), 793-819. https://doi.org/10.1177/0192513X05277542

Hobfoll, S. E. (1989). Conservation of resources: A new attempt at conceptualizing stress. American Psychologist, 44(3), 513-524. https://doi.org/10.1037/0003-066X.44.3.513

Jermsittiparsert, K. (2016). Culture of 'Elephant front legs-hind legs': A debate on the actuality of sexual politics in Thai society. The Social Sciences, 11(1), 20-28.

Judge, T. A., Boudreau, J. W., \& Bretz, R. D. (1994). Job and life attitudes of male executives. Journal of Applied Psychology, 79(5), 767-782. https://doi.org/10.1037/0021-9010.79.5.767

Locke E. A. (1976). The nature and causes of job satisfaction. Handbook of Industrial and Organizational Psychology. Chicago: Rand McNally.

Major, D. A., \& Germano, L. M. (2006). The changing nature of work and its impact on the work-home interface. In F. Jones (Eds.), Work-life balance: A psychological perspective (pp. 13-38). East Sussex: Psychology Press.

McNall, L. A., Masuda, A. D., \& Nicklin, J. M. (2009). Flexible work arrangements, job satisfaction, and turnover intentions: The mediating role of work-to-family enrichment. The Journal of Psychology, 144(1), 61-81. 
McNall, L. A., Masuda, A. D., Shanock, L. R., \& Nicklin, J. M. (2011). Interaction of core self-evaluations and perceived organizational support on work-to-family enrichment. The Journal of Psychology, 145(2), 133-149.

McNall, L. A., Nicklin, J. M., \& Masuda, A. D. (2010). A meta-analytic review of the consequences associated with work-family enrichment. Journal of Business and Psychology, 25(3), 381-396.

Mossholder, K. W., Settoon, R. P., \& Henagan, S. C. (2005). A relational perspective on turnover: Examining structural, attitudinal, and behavioral predictors. Academy of Management Journal, 48(4), 607-618.

Onuoha, B. C., Umoh, E. D., \& Ufomba, H. (2017). The Impact of the Politics of Privatization and Commercialization of Public Enterprises in Nigeria on the Level of Productivity and Economic Viability: The Case of Alscon and Nitel. Asian Development Policy Review, 5(1), 43-55.

Oshagbemi, T. (2000). Gender differences in the job satisfaction of university teachers. Women in Management Review, 15(7), 331-343. https://doi.org/10.1108/09649420010378133

Rainey, H. G. (2009). Understanding and managing public organizations. San Francisco: John Wiley \& Sons.

Robbins, S. P. (2003). Organizational behavior: concepts, controversies, applications (8th ed.). New Jersey, USA: Publisher: Prentice-Hall International.

Sangakala, M., Ahmed, U., \& Pahi, M. H. (2016). Empirical investigating on the role of supervisor support, job clarity, employee training and performance appraisal in addressing job satisfaction of nurses. International Business Management, 10(23), 5481-5486.

Shein, J., \& Chen, C. P. (2011). Work-family enrichment: A research of positive transfer. Rotterdam: Sense Publishers. https://doi.org/10.1007/978-94-6091-382-2

Shi, W., \& Qu, P. (2018). A Comparative Study on Chinese and English Compliments from the Perspective of Intercultural Communication. International Journal of English Language and Literature Studies, 7(4), 133-137.

Shin, D. C., \& Johnson, D. M. (1978). Avowed happiness as an overall assessment of the quality of life. Social Indicators Research, 5(1-4), 475-492. https://doi.org/10.1007/BF00352944

Shockley, K. M., \& Singla, N. (2011). Reconsidering work-family interactions and satisfaction: A meta-analysis. Journal of Management, 37(3), 861-886. https://doi.org/10.1177/0149206310394864

Sieber, S. D. (1974). Toward a theory of role accumulation. American Sociological Review, 39(4), 567-578.

Stoner, C. R., Hartman, R. I., \& Arora, R. (1990). Work/family conflict: a study of women in management. Journal of Applied Business Research, 7(1), 67-74. https://doi.org/10.19030/jabr.v7i1.6261

Tait, M., Padgett, M. Y., \& Baldwin, T. T. (1989). Job and life satisfaction: A reevaluation of the strength of the relationship and gender effects as a function of the date of the study. Journal of Applied Psychology, 74(3), 502-507. https://doi.org/10.1037/0021-9010.74.3.502

Tolulope, A. (2017). Demographic Variables as Factors Influencing Accessibility and Utilisation of Library Software by Undergraduates in Two Private Universities in Nigeria. Journal of Education and e-Learning Research, 4(3), 92-99. https://doi.org/10.20448/journal.509.2017.43.92.99

Verma, C., Stoffova, V., \& Zoltan, I. (2018). Perception difference of Indian students towards infor-mation and communication technology in context of University Affiliation. Asian Journal of Contemporary Education, 2(1), 36-42. https://doi.org/10.20897/ejosdr/74240

Wadsworth, L. L., \& Owens, B. P. (2007). The effects of social support on work-family enhancement and workfamily conflict in the public sector. Public Administration Review, 67(1), 75-87. https://doi.org/10.1111/j.1540-6210.2006.00698.x

Wayne, J. H., Musisca, N., \& Fleeson, W. (2004). Considering the role of personality in the work-family experience: Relationships of the big five to work-family conflict and facilitation. Journal of Vocational Behavior, 64(1), 108-130. https://doi.org/10.1016/S0001-8791(03)00035-6

Wayne, J. H., Randel, A. E., \& Stevens, J. (2006). The role of identity and work-family support in work-family enrichment and its work-related consequences. Journal of Vocational Behavior, 69(3), 445-461.

Williams, A., Franche, R. L., Ibrahim, S., Mustard, C. A., \& Layton, F. R. (2006). Examining the relationship between work-family spillover and sleep quality. Journal of Occupational Health Psychology, 11(1), 27-37. https://doi.org/10.1037/1076-8998.11.1.27 